MatgorZata Bajgier-Kowalska

Krakowska Akademia im. Andrzeja Frycza Modrzewskiego w Krakowie, Polska - Andrzej Frycz Modrzewski Krakow University, Poland

Mariola Tracz

Szkoła Wyższa im. Bogdana Jańskiego w Krakowie, Polska - Faculty in Kraków, Poland

RADOSŁAW ULISZAK

Krakowska Akademia im. Andrzeja Frycza Modrzewskiego w Krakowie, Polska - Andrzej Frycz Modrzewski Krakow University, Poland

\title{
Uwarunkowania rozwoju przedsiębiorczości na obszarach wiejskich na przykładzie gospodarstw agroturystycznych województwa małopolskiego
}

\author{
Conditions for Development of Entrepreneurship in Rural Areas on the Example \\ of Agritourism Farms in the Małopolska Voivodeship
}

Streszczenie: W ostatnich latach najprężniej rozwijającą się formą turystyki wiejskiej i równocześnie przejawem przedsiębiorczości rolników jest agroturystyka. Jej istota wiąże się ze świadczeniem usług przez funkcjonujące gospodarstwo rolne i jego otoczenie. To trend w rozwoju współczesnej turystyki, polegający na rosnącym zainteresowaniu turystyką przyjazną środowisku. Głównym celem tego rodzaju turystyki jest dbałość o zachowanie trwałego, zrównoważonego rozwoju zasobów i walorów turystycznych przez integrację działalności turystycznej z celami ochrony przyrody oraz życiem społeczno-gospodarczym. Celem artykułu jest ukazanie uwarunkowań rozwoju agroturystyki w województwie małopolskim oraz jej stanu i zachodzących zmian w tym zakresie. Podstawą charakterystyki badanego problemu była analiza literatury przedmiotu, danych o liczbie gospodarstw agroturystycznych na podstawie materiałów zawartych w rocznikach statystycznych GUS i innych źródłach publikowanych oraz zebranych przez autorów informacji z oficjalnych portali internetowych gmin i powiatów dotyczących turystyki, w tym agroturystyki. Autorzy oszacowali aktualną liczbę gospodarstw agroturystycznych $\mathrm{w}$ regionie i dokonali analizy profilu ich działalności. W celu uzupełnienia i weryfikacji zebranego materiału przeprowadzili badania ankietowe w 175 losowo wybranych gospodarstwach. Badania miały charakter indywidualnych wywiadów pogłębionych $\mathrm{z}$ właścicielami gospodarstw, dotyczących prowadzonej działalności i oferowanych usług. Istniejące $\mathrm{w}$ województwie małopolskim uwarunkowania demograficzne, przyrodnicze i historyczne powodują, że w strukturze agrarnej rolnictwa przeważają i przeważać będą drobnotowarowe i samozaopatrzeniowe gospodarstwa. W tych warunkach istotnym wyzwaniem dla działań przedsiębiorczych wśród rolników prowadzących agroturystykę jest przezwyciężenie, wynikającej z przeszłości historycznej, niechęci do wszelkich form zrzeszania się i wspólnych inicjatyw. Wspólne inicjatywy w zakresie kreowania nowych ofert turystycznych, powiązanych z istniejącymi zasobami i ich promocja mogą stanowić kluczową kwestię w zakresie przetrwania i rozwoju małych gospodarstw rolnych i powiązanych z nimi usług turystycznych.

\footnotetext{
Abstract: Agritourism seems to be the fastest growing form of rural tourism and at the same time a manifestation of entrepreneurship of farmers in recent years. It's essence relates to the provision of services by operating farm and its surroundings. Its essence relates to the provision of services by operating a farm and its surroundings. It's a trend in the development of modern tourism, relies on growing
} 
interest in environmentally friendly tourism. The main purpose of this type of tourism is to care for the preservation of sustainable resource development and tourism values through the integration of tourism activities with the objectives of nature conservation and socio-economic life. The aim of the study is to show conditions for the development of agritourism in the Małopolska Voivodeship and its state and ongoing changes. The basis of the characteristics of a given problem was to analyze literature, data on the number of tourist farms based on the materials contained in the statistical yearbooks and other sources published and collected by the authors from official web portals of municipalities and counties on tourism, including agritourism. The authors estimated the number of farms in the region and analyzed their activities. In order to supplement and verify the collected material a survey was carried out in 175 randomly selected farms. In-depth interviews with landowners about your business and services have been conducted.Natural, historical and demographic conditions existing in the Małopolska province cause that the agrarian structure is and will be dominated by agriculture and small-scale farms. Under these conditions, a major challenge for entrepreneurial activities among farmers engaged in agritourism is to overcome resulting from the historical past the aversion to all forms of association and joint initiatives. Joint initiatives in this area by creating new tourism offers related to existing resources and to promote them may be a key issue in terms of survival and development of small farms and related tourist services.

Słowa kluczowe: agroturystyka; przedsiębiorczość; rolnictwo; turystyka, wieś

Key words: agriculture; agritourism; countryside; entrepreneurship; tourism

Otrzymano: 11 listopada 2015

Received: 11 November 2015

Zaakceptowano: 29 lutego 2016

Accepted: 29 February 2016

\section{Sugerowana cytacja/Suggested citation:}

Bajgier-Kowalska, M., Tracz, M., Uliszak, R. (2016). Uwarunkowania rozwoju przedsiębiorczości na obszarach wiejskich na przykładzie gospodarstw agroturystycznych województwa małopolskiego. Przedsiębiorczość - Edukacja, 12, 256-273.

\section{Wstęp}

W rozwoju współczesnej turystyki można zaobserwować rosnące zainteresowanie turystyką przyjazną środowisku, której głównym celem jest zachowanie trwałego, zrównoważonego rozwoju zasobów i walorów turystycznych przez integrację działalności turystycznej z celami ochrony przyrody oraz życiem społeczno-gospodarczym. Jedną z jej form jest turystyka na obszarach wiejskich, wykorzystująca walory tego środowiska. Cechuje ją bliskość natury, osobisty kontakt z mieszkańcami wsi, aktywny wypoczynek oraz pobyt na terenach o mniejszej gęstości zaludnienia. W Europie Zachodniej zaspokaja ona 10\% popytu na usługi wypoczynkowe. Przeciętnie 3-5\% gospodarstw rolnych świadczy takie usługi. Liderami w tym zakresie są: Włochy, Francja, Wielka Brytania, Austria i Niemcy. Turystyka wiejska prężnie rozwija się także w krajach skandynawskich (Kurdyś-Kujawska, 2010; Eurostat, 2014). Stanowi ona coraz częściej jedną z ważniejszych dziedzin gospodarki lokalnej i jest jedną z wielu dróg gospodarczego ożywienia obszarów wiejskich i ich wielofunkcyjnego zagospodarowania (Bieńkowski, 2001; Jędrysiak, 2010). Również w Polsce obserwuje się istotne działania będące przejawem aktywności i przedsiębiorczości samorządów lokalnych oraz mieszkańców, sprzyjające rozwojowi różnych form turystyki na obszarach wiejskich.

W ostatnich latach najprężniej rozwijającą się formą turystyki wiejskiej i równocześnie przejawem przedsiębiorczości rolników jest agroturystyka. Tradycyjnie pod tym pojęciem 
rozumie się wypoczynek odbywający się w funkcjonującym gospodarstwie rolnym i jego otoczeniu (Butler, 1998; Drzewiecki, 2001; Roberts, Hall, 2001; Durydiwka, 2003; Sznajder, Przezbórska, 2006; Phillip, Hunter, Blackstock i in., 2010). Niektórzy badacze traktują agroturystykę znacznie szerzej, utożsamiając ją z turystyką wiejską (Gannon, 1994; Busby, Rendle, 2000). Inni zaś pod tym terminem rozumieją wszelką działalność, przedsięwzięcie lub biznes podejmowane $\mathrm{w}$ celu podniesienia atrakcyjności obszarów wiejskich i ich otoczenia, a tym samym przyczyniającą się do poprawy jakości życia na wsi (McGehee, Kim, 2004; Colton, Bissix, 2005; Fleischer, Tchetchik, 2005). Agroturystyka jest jedną z form pozarolniczej działalności rodzin rolniczych, które decydują się na organizowanie pobytu turystów we własnym gospodarstwie rolnym, a więc jej rozwój jest kreowaniem przedsiębiorczości na wsi. Rozwój turystyki na obszarach wiejskich jest wynikiem procesów odzwierciedlających interesy zarówno ludności miejskiej, w zaspokajaniu potrzeby taniego, spokojnego oraz zdrowego wypoczynku i rekreacji, jak i rolników. Dla nich stanowi ona dodatkowe źródło dochodów, sprzyja rozwojowi postaw przedsiębiorczych, podnoszeniu kwalifikacji i kompetencji zawodowych i osobowych oraz jakości infrastruktury mieszkalnej. Wzbogaca również budżet samorządowy, daje możliwości rozwoju innych działalności, podnosi standard i jakość życia mieszkańców, a także sprzyja zachowaniu tradycji i kultury wiejskiej.

Celem opracowania jest ukazanie uwarunkowań rozwoju agroturystyki jako jednej z form przedsiębiorczości na obszarach wiejskich w województwie małopolskim oraz jej stanu i zachodzących zmian w tym zakresie. W szczególności chodzi o udzielenie odpowiedzi na pytanie: na ile uwarunkowania przyrodniczo-kulturowe oraz społeczno-gospodarcze wpływają na rozwój agroturystyki w analizowanym regionie. Ponadto próbowano ustalić czynniki determinujące i ograniczające dalszy rozwój agroturystyki w poszczególnych gminach oraz powiatach. Podstawą charakterystyki badanego problemu była analiza literatury przedmiotu, danych o liczbie gospodarstw agroturystycznych na podstawie materiałów zawartych w rocznikach statystycznych GUS i innych źródłach publikowanych (informatory Małopolskiego Ośrodka Doradztwa Rolniczego, Instytutu Turystyki, Polskiej Organizacji Turystycznej, Małopolska agroturystyka. Atlas gospodarstw agroturystycznych) oraz zebranych przez autorów informacji $\mathrm{z}$ oficjalnych portali internetowych gmin i powiatów dotyczących turystyki, w tym agroturystyki. W wyniku analizy zebranych danych oszacowano liczbę gospodarstw agroturystycznych w województwie małopolskim w 2014 r. na 1259 obiektów. Autorzy dokonali analizy ich profili, a w celu uzupełnienia i weryfikacji zebranego materiału przeprowadzili badania ankietowe w 175 losowo wybranych gospodarstwach położonych w różnych częściach województwa. Miały one charakter indywidualnych wywiadów pogłębionych z właścicielami gospodarstw, dotyczących prowadzonej działalności i oferowanych usług.

\section{Agroturystyka jako przykład przedsiębiorczości na obszarach wiejskich}

Pojęcie przedsiębiorczości jest różnie definiowane. Wielu autorów jest zdania, że przedsiębiorczość to zachowania ludzi idące w kierunku podejmowania nowych, ulepszających działań wobec otaczającej ich rzeczywistości. Istotną rolę w tych działaniach odgrywają określone cechy osobowości, takie jak np. pomysłowość, zaradność, inicjatywa. Z jednej strony przedsiębiorczość jest ideą, a z drugiej - pewnym kierunkiem myślenia, który pozwala jednostce dokonywać istotnych zmian w sposobach gospodarowania. Jednocześnie ma ona prawo, jako aktywny podmiot, do uczestniczenia w tworzeniu i przekształcaniu gospodarki (Drucker, 1992; Zioło, 2007; Krzyżanowska, 2010). Przedsiębiorczość można także rozumieć jako zachowania 
władz i miejscowej ludności, które zmierzają do poszukiwania nowych zastosowań posiadanych zasobów w celu aktywizacji gospodarczej regionu i zwiększenia jego konkurencyjności (Majewska, 2006). Jest to sposób działania na rynku, dający wyższą użyteczność produktów i usług oraz większą efektywność gospodarowania. Polega na skłonności do podejmowania nowych, niekiedy ryzykownych i niekonwencjonalnych przedsięwzięć oraz na wykazywaniu inicjatywy w ich poszukiwaniu i wdrażaniu w życie (Fabiańska, 1986; Kortan, 1997). Przedsiębiorczość stanowi jeden z podstawowych warunków rozwoju gospodarczego, społecznego i kulturowego układów przestrzennych różnej skali (Zioło, 2007, 2011). Problematyka związków pomiędzy przedsiębiorczością a szeroko pojmowanym rozwojem regionalnym, w tym również instytucjonalnym i przestrzennym wymiarem gospodarowania oraz konkurencyjności, jest ważnym i często podejmowanym tematem badań, niejednokrotnie o charakterze interdyscyplinarnym (Krajewski, Śliwa, 2004; Zioło, 2006, 2007, 2011; Zdon-Korzeniowska, 2009, 2011; Kuciński, 2010; Bednarczyk, 2010; Dorocki i in., 2012).

W aktualnej strategii rozwoju obszarów wiejskich zakłada się, że wieś powinna rozwijać się wielokierunkowo, co przyczyni się do dywersyfikacji źródeł dochodów rolników. Jednym z przejawów przystosowania gospodarki rolnej do warunków rynkowych jest upowszechnianie i wdrażanie idei przedsiębiorczości wśród mieszkańców wsi. Uważa się, że może ona istotnie wpłynąć na zachowania rolników oraz stymulować powstawanie innych podmiotów gospodarczych, które przyczynią się do zwiększenia dochodów rolników i pozostałych mieszkańców wsi (Sikora, Jęczmyk, 2006; Sikora, 2008). Według Powszechnego Spisu Rolnego z 2010 r. najwięcej dochodów z działalności pozarolniczej uzyskują rolnicy w województwie małopolskim $(13,29 \%)$ i podkarpackim $(13,2 \%)$, co ma swoje uzasadnienie m.in. w strukturze agrarnej, uwarunkowaniach przyrodniczych oraz tradycji gospodarstw rodzinnych (Systematyka..., 2011).

Rozwój postaw przedsiębiorczych zdeterminowany jest przez oddziaływanie czynników wewnętrznych i zewnętrznych. W odniesieniu do obszarów wiejskich do czynników wewnętrznych zaliczyć należy cechy rolnika, jego gospodarstwa rolnego oraz pozostałych mieszkańców wsi. W przypadku rolnika dotyczą one jego cech społeczno-demograficznych (wiek, płeć, wykształcenie, doświadczenie zawodowe) oraz cech osobowościowych (zaradność, obrotność, podatność na innowacje, odporność na ryzyko). Zaś do wewnętrznych czynników warunkujących działalność gospodarstwa rolnego należą m.in.: powierzchnia (obszar) gospodarstwa, struktura produkcji, stan i jakość majątku produkcyjnego oraz potencjał ekonomiczny. Natomiast do czynników zewnętrznych wpływających na podejmowane inicjatywy przedsiębiorcze na wsi zalicza się przede wszystkim warunki ekonomiczne (tj. popyt, podaż, ceny na produkty rolne, warunki kredytowania produkcji), warunki agrarno-przyrodnicze oraz prawne, a także politykę rolną państwa. Zarówno czynniki wewnętrzne, jak i zewnętrzne determinują rozwój przedsiębiorczości, jej tempo, kierunek oraz formy produkcji w rolnictwie i pozarolniczej działalności (Sikora, 2008; Krzyżanowska, 2010; Gospodarka..., 2012; Semczuk i in., 2013).

Agroturystyka jest obecnie pojęciem szerokim, gdyż oprócz wypoczynku na wsi obejmuje ona swoim zasięgiem szereg innych usług towarzyszących. Jest klasyfikowana jako jedna z form turystyki wiejskiej, związanej bezpośrednio z gospodarstwem rolnym. Należy jednak zaznaczyć, że gospodarstwa agroturystyczne w Polsce funkcjonują w ramach gospodarstw rolnych lub też są indywidualną działalnością gospodarczą prowadzoną na własny rachunek, zgodnie z ustawą o swobodzie działalności gospodarczej oraz o podatku dochodowym i w różnych formach organizacyjno-prawnych.

Zgodnie z aktualnie obowiązującymi normami prawnymi za agroturystykę, która nie jest traktowana jako działalność gospodarcza i nie podlega opodatkowaniu, uważana jest 
działalność polegająca na wynajmowaniu (z wyżywieniem lub bez) wypoczywającym osobom nie więcej niż pięciu pokoi gościnnych w budynkach mieszkalnych położonych na terenach wiejskich w gospodarstwie rolnym (Dz.U. 2004, 2010).

\section{Strategia rozwoju obszarów wiejskich w województwie małopolskim}

W dokumencie Strategia rozwoju województwa małopolskiego na lata 2011-2020 (2011) i Kierunki rozwoju turystyki dla województwa małopolskiego na lata 2008-2013 (2008) wskazano, że istotnym działaniem w rozwoju województwa będzie turystyka. Realizację tego działania zaprogramowano w następujących obszarach: dziedzictwo i przemysły czasu wolnego, rozwój miast i terenów wiejskich oraz bezpieczeństwo ekologiczne, zdrowotne i społeczne (Strategia..., 2011). Działalność turystyczna na obszarach wiejskich, w tym agroturystyka i ekoturystyka, postrzegana jest także jako wsparcie ekonomiczne gospodarstw rolnych i ludności wiejskiej (Turystyka wiejska..., 2012). Uważa się, że ekoturystyka, powiązana z pokrewnymi jej formami gospodarowania, takimi jak zrównoważone rolnictwo i przetwórstwo, rzemiosło i winiarstwo, oraz z innymi formami turystyki alternatywnej może być ważnym stymulatorem rozwoju obszarów wiejskich w województwie małopolskim. Jeśli będzie ona realizowana w synergii z innymi formami przedsiębiorczości na terenach wiejskich, może stać się swoistą cechą wyróżniającą ten obszar w kraju (Gospodarka..., 2012).

$\mathrm{Na}$ obszarach najbardziej atrakcyjnych przyrodniczo (Tatry i Podhale, Pieniny, Beskid Sądecki i Wyspowy) postuluje się rozwój wsi turystycznych z bogatą ofertą tradycyjnej kultury i rozwiniętą agroturystyką (Uliszak, 2013). Agroturystyka i powiązane z nią inicjatywy powinny odgrywać istotną rolę w rozwoju aktywności zawodowej, wzmacnianiu i promocji przedsiębiorczości na terenach wiejskich, tworzeniu nowych miejsc pracy, pobudzaniu rozwoju małych i średnich przedsiębiorstw w produkcji rolniczej i pozarolniczej.

Uwzględniając współczesne tendencje w produkcji rolniczej, a także ekologii i ochronie środowiska, jako preferowany typ gospodarowania na terenie województwa małopolskiego wskazuje się raczej rozwój rolnictwa tradycyjnego. Rolnictwo tradycyjne rozumiane jest jako gospodarstwa rodzinne podlegające pokoleniowemu dziedziczeniu w zakresie nie tylko zasobów majątkowych (kapitału), lecz także technologii produkcji oraz różnorodnych aspektów kulturowych, związanych z pracą i życiem na wsi (Gospodarka..., 2012). Stosowanie tradycyjnych metod produkcji przez gospodarstwa rodzinne sprzyja zachowaniu specyficznych siedlisk przyrodniczych i różnorodności biologicznej w regionie. Również w raportach wskazuje się na potrzebę wsparcia tradycyjnego chowu zwierząt gospodarskich, w tym w gospodarstwach drobnotowarowych. Jednym ze sposobów może być wyeksponowanie znaczenia zwierząt (krowy, konie, owce) w kulturze rolnej regionu. Odnosi się to także do tradycyjnych form wypasu zwierząt w wyższych partiach gór. Ponadto zwiększenia wymagają działania zmierzające do wypromowania produktów wytwarzanych w drobnych gospodarstwach rolnych i zapewnienia lepszych warunków ich zbytu (Gospodarka..., 2012).

\section{Uwarunkowania przyrodnicze i kulturowe rozwoju agroturystyki w województwie małopolskim}

Opracowane waloryzacje warunków przyrodniczych dla potrzeb rozwoju turystyki wskazują, że najatrakcyjniejsze regiony dla rozwoju agroturystyki to: wybrzeże Morza Bałtyckiego, 
pojezierza, Karpaty i Sudety (Durydiwka, 2012; Turystyka wiejska..., 2012; Bednarek-Szczepańska, Bański, 2014). W przyjętej klasyfikacji obszary województwa małopolskiego zajmują bardzo wysoką pozycję. Warunki przyrodnicze województwa sprzyjają rozwojowi turystyki, gdyż 52,1\% jego powierzchni podlega ochronie prawnej (6 parków narodowych, 11 parków krajobrazowych, 85 rezerwatów przyrody, 10 obszarów chronionego krajobrazu, 2209 pomników przyrody), a dużym bogactwem są zasoby wód mineralnych i termalnych (Rocznik Statystyczny... 2014). Ponadto o wyjątkowych walorach przyrodniczych świadczy największe w Polsce zróżnicowanie krajobrazu, głównie górskiego - Tatry, Pieniny, Beskidy - oraz wyżynnego - Wyżyna Krakowsko-Częstochowska i Wyżyna Miechowska.

Województwo małopolskie posiada także bardzo bogate dziedzictwo kulturowe, które stanowi podstawę jego unikalności i atrakcyjności turystycznej. Na Liście światowego dziedzictwa UNESCO znajduje się 14 zespołów i obiektów zabytkowych z tego regionu, w tym 8 na obszarach wiejskich. Równocześnie region oferuje bogate środowisko kulturowe: tradycje, obrzędy, stroje, bogatą i różnorodną kuchnię oraz formy gospodarowania (np. pasterstwo, pszczelarstwo, rękodzielnictwo). Liczne są imprezy kulturalne (festiwale, targi wyrobów lokalnych), sztuka ludowa, tradycyjna architektura i budownictwo oraz muzyka.

\section{Cechy gospodarki rolnej województwa małopolskiego sprzyjające rozwojowi agroturystyki}

Tereny wiejskie stanowią 89,09\% powierzchni województwa małopolskiego. W $2014 \mathrm{r}$. liczba ludności województwa wynosiła $3,4 \mathrm{mln}$, z czego 61\% mieszkało na wsi (Rocznik Statystyczny..., 2014). Według danych Powszechnego Spisu Rolnego w 2010 r. na terenie województwa funkcjonowało 283,3 tys. gospodarstw rolnych, głównie indywidualnych $(99,9 \%)$. Dominują drobne gospodarstwa rolne, o powierzchni użytków rolnych poniżej 1 ha $-42,8 \%$. Większość z tych gospodarstw nie posiada już zabudowań gospodarczych, a ziemia dzierżawiona jest sąsiadom bądź pozostawiona odłogiem. Wśród ogółu gospodarstw w województwie $78,1 \%$ prowadziło produkcję rolniczą. Wśród nich $56,7 \%$ gospodarstw prowadziło zarówno produkcję roślinną, jak i zwierzęcą, 42,0\% - tylko produkcję roślinną, a 1,3\% - wyłącznie produkcję zwierzęcą (Powszechny Spis..., 2011; Gospodarka..., 2012). Rolnicy z niektórych regionów województwa małopolskiego specjalizują się także w produkcji warzyw i owoców na rynek lokalny i krajowy.

W strukturze użytkowania ziemi w województwie małopolskim dominują użytki rolne blisko $62 \%$ powierzchni, lasy stanowią $28,7 \%$, a pozostałe grunty - 9,3\%. Obserwuje się wzrost udziału gruntów leśnych oraz pozostałych gruntów kosztem użytków rolnych (Powszechny Spis..., 2011). Z danych z Powszechnego Spisu Rolnego z 2010 r. wynika, że w porównaniu z 2002 r. zmniejszyła się ogólna powierzchnia zasiewów o 20,0\% (76,6 tys. ha). Odnotowano także zmniejszenie się powierzchni upraw zbóż ogółem (o 19,1\%), ziemniaków (o 43,4\%) i roślin pastewnych (o 23,4\%). Natomiast zwiększyła się powierzchnia upraw roślin przemysłowych (o 71,3\%) i strączkowych jadalnych (o 14,8\%). Również pogłowie bydła było niższe o 30\% w porównaniu z 2002 r. Spadki pogłowia bydła odnotowano przede wszystkim w gospodarstwach najmniejszych, w których rolnicy całkowicie zrezygnowali z utrzymywania zwierząt. Pogłowie owiec w 2010 r. liczyło 69,9 tys. sztuk (spadek o ok. 16,5\%), co stanowiło ponad 1/4 populacji owiec w Polsce. W przypadku pozostałych grup zwierząt, tj. trzody oraz koni, spadki pogłowia sięgają ponad 30\% (Powszechny Spis..., 2011). 
Z danych GUS wynika, że od 2009 r. systematycznie wzrasta produkcja towarowa małopolskich gospodarstw rolnych. Świadczy to m.in. o zwiększeniu zakresu kontaktów rynkowych gospodarstw rolnych oraz o koncentracji produkcji towarowej. Wyniki te generują przede wszystkim gospodarstwa większe obszarowo. Większość drobnych gospodarstw rolnych (do 1 ha) w minimalnym stopniu uczestniczy w wymianie rynkowej. Wynika to z małej skali produkcji, a także ze zmienności cen skupu produktów rolnych (Gospodarka..., 2012).

W województwie małopolskim uwidacznia się problem nadmiaru zatrudnionych w rolnictwie. W 2010 r. w gospodarstwach rolnych pracowało łącznie 270 tys. osób, z czego 222,3 tys. wyłącznie we własnym gospodarstwie. Wskaźnik zatrudnionych w rolnictwie na 100 ha UR dla województwa małopolskiego jest ponad dwukrotnie wyższy niż średnio w Polsce (Powszechny Spis..., 2011; Gospodarka..., 2012). Skłania to od dawna rolników do poszukiwania zatrudnienia poza rolnictwem lub dodatkowych źródeł zarobkowania (np. agroturystyka, ekoturystyka, usługi transportowe czy budowlane) oraz świadczenia usług kulturowych (np. gospodarstwa edukacyjne, wytwarzanie produktów lokalnych i tradycyjnych). Szczególnie w gminach atrakcyjnych przyrodniczo ludność często podejmuje działalność związaną z usługami turystycznymi (Przygodzka, 1997; Bański, Stola, 2001; Durydiwka, 2003, 2013; Kierunki..., 2008; Wojciechowska, 2009).

Podsumowując, można stwierdzić, że warunki przyrodnicze i wadliwa struktura agrarna stawiają rolników województwa małopolskiego na gorszej pozycji w prowadzeniu działalności rolniczej w porównaniu z innymi województwami. Przekłada się to na ich większe nakłady przy niższych dochodach $\mathrm{z}$ tego tytułu. $\mathrm{Z}$ drugiej strony takie uwarunkowania społeczno-gospodarcze wymuszają podejmowanie nowych wyzwań i kreowanie zachowań przedsiębiorczych wśród ludności. Jednocześnie, z powodu rozdrobnienia gospodarstw, oferowana turystyka jest skazana na korzystanie w dużym stopniu z terenów prywatnych lub publicznych nienależących do gospodarstwa przyjmującego turystów. Może to sprzyjać tworzeniu się sąsiedzkiej lub gminnej współpracy w rozwoju usług turystycznych, a z drugiej strony wywoływać konflikty pomiędzy zainteresowanymi rozwojem turystyki a tymi, którym to przeszkadza.

Innym czynnikiem ograniczającym funkcjonowanie i przyszłość turystyki na obszarach wiejskich jest konflikt interesów w obrębie społeczności lokalnych. Osoby zainteresowane prowadzeniem usług turystycznych często są zwolennikami poszerzania terenów prawnie chronionych (np. parków narodowych, krajobrazowych) jako bazy do dalszego rozwoju ruchu turystycznego. W tym samym czasie inne grupy stawiają na odmienne sposoby wykorzystania tych terenów (np. pozyskiwanie drewna, tereny pod budownictwo).

Regionalne zróżnicowanie poziomu rozwoju usług agroturystycznych w województwie małopolskim

Rozwój działalności agroturystycznej jest efektem nie tylko uwarunkowań o charakterze przyrodniczym, kulturowym, społecznym i ekonomicznym, lecz także przejawem aktywności i postaw przedsiębiorczych rolników. Dzięki korzystnym warunkom przyrodniczo-kulturowym, dużej liczbie atrakcji oraz tradycji obsługi ruchu turystycznego województwo małopolskie jest znaczącym podmiotem na krajowym rynku agroturystycznym (Bański, 2010; Dorocki i in., 2012, 2013; Bednarek-Szczepańska, Bański, 2014).

W latach 1998-2014 liczba gospodarstw agroturystycznych w omawianym województwie stale wzrastała (tab. 1). Najwięcej tego typu podmiotów powstało w latach 1999-2010. 


\begin{tabular}{|c|c|c|c|c|c|c|}
\hline$\underset{\sim}{\mathbb{N}}$ & 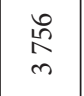 & $\overbrace{\infty}$ & $\begin{array}{l}\stackrel{0}{\infty} \\
\infty \\
\simeq\end{array}$ & $\stackrel{\stackrel{ }{\mathrm{N}}}{-}$ & 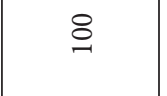 & 会 \\
\hline$\overline{\vec{\sigma}}$ & $\begin{array}{l}\sim \\
\infty \\
\sim\end{array}$ & î & $\begin{array}{l}\text { J゙ } \\
\text { I } \\
\text { D }\end{array}$ & $\underset{-}{\stackrel{H}{-}}$ & $\hat{\sigma}$ & $\begin{array}{l}\stackrel{\widehat{O}}{\sigma} \\
\underline{-1}\end{array}$ \\
\hline 옹 & જ̊ & ஓ & $\begin{array}{l}\stackrel{i}{\aleph} \\
\infty \\
\infty\end{array}$ & 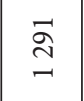 & 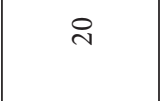 & $\begin{array}{l}\text { io } \\
i n \\
\text { in }\end{array}$ \\
\hline ठ্ेે & $\begin{array}{l}\stackrel{\text { }}{ } \\
\text { ○ }\end{array}$ & & ஜু & $\stackrel{\text { ஸे }}{\text {. }}$ & & ুু \\
\hline ¿ે̊ి & $\begin{array}{l}\stackrel{શ}{\infty} \\
\infty\end{array}$ & & $\begin{array}{l}\underset{+}{\mathbb{N}} \\
\underset{\infty}{1}\end{array}$ & $\begin{array}{l}\text { 号 } \\
\text { in }\end{array}$ & & 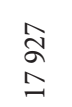 \\
\hline ¿̊̀ & $\underset{\sim}{\stackrel{\sim}{N}}$ & & $\begin{array}{l}\stackrel{8}{0} \\
i \\
i\end{array}$ & $\underset{\sim}{\stackrel{ }{~}}$ & & $\begin{array}{l}\stackrel{n}{\kappa} \\
\stackrel{2}{n}\end{array}$ \\
\hline 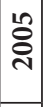 & $\begin{array}{l}\text { 命 } \\
\text { రు }\end{array}$ & & $\begin{array}{l}\stackrel{8}{8} \\
\text { Vర }\end{array}$ & & & \\
\hline ঠి & 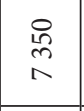 & & & $\stackrel{\mathscr{P}}{\rightleftarrows}$ & & 윰 \\
\hline ఫิి & & & & ถิ & & 岂 \\
\hline ஓ्্ે & $\begin{array}{l}\underset{\infty}{\infty} \\
\text { in }\end{array}$ & & $\begin{array}{l}8 \\
8 \\
\text { กิ }\end{array}$ & $\underset{J}{ \pm}$ & & తి \\
\hline Әे & $\begin{array}{l}\mathfrak{g} \\
\dot{\sigma}\end{array}$ & & $\begin{array}{l}\stackrel{\overbrace{}}{I} \\
\text { 아 }\end{array}$ & $\underset{\sim}{\infty}$ & & 욤 \\
\hline$\stackrel{\infty}{2}$ & $\begin{array}{l}\text { ڤू } \\
\text { mे }\end{array}$ & & $\begin{array}{l}\text { 으 } \\
\text { in } \\
\text { ñ }\end{array}$ & $\widehat{\Xi}$ & & $\underset{\sigma}{\overparen{Z}}$ \\
\hline$\stackrel{\text { }}{\approx}$ & 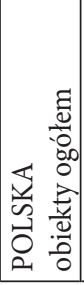 & 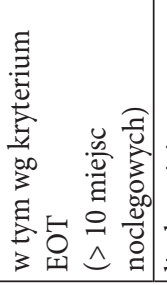 & 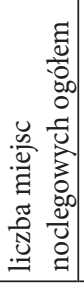 & 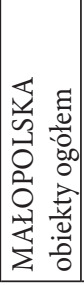 & 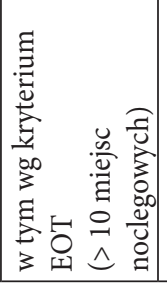 & 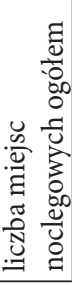 \\
\hline
\end{tabular}


Aktualnie liczba gospodarstw agroturystycznych nieznacznie się zmniejszyła (tab. 1). Należy zaznaczyć, że dane o liczbie gospodarstw agroturystycznych publikowane w rocznikach statystycznych i innych materiałach (np. Ośrodków Doradztwa Rolniczego, stowarzyszeń agroturystycznych) są szacunkowe. Ze względu na przyjęte kryteria formalno-prawne, dotyczące prowadzonej przez rolników działalności agroturystycznej, liczba podmiotów funkcjonujących jest na ogół wyższa od tych podawanych w oficjalnych statystykach (Krzyżanowska, 2010). Różnice między liczbą gospodarstw agroturystycznych podawaną od 2010 r. przez GUS a liczbą faktycznie istniejących gospodarstw wynikają ze zmiany stosowanego kryterium ewidencji działalności agroturystycznej. Obecnie GUS rejestruje tylko gospodarstwa, które posiadają $10 \mathrm{i}$ więcej miejsc noclegowych. Zebrane przez autorów dane z oficjalnych portali turystycznych gmin i powiatów województwa wskazują na znacznie większą liczbę funkcjonujących gospodarstw w tym regionie (tab. 1). W wyniku dokonanej analizy danych oszacowano liczbę gospodarstw agroturystycznych na 1259 obiektów. Poddano je szczegółowej analizie przestrzennej i ocenie w zakresie oferowanego produktu.

Obszar województwa małopolskiego jest bardzo zróżnicowany pod względem oferty agroturystycznej (ryc. 1, tab. 2). Regionami o silnej pozycji są powiaty położone w południowej części województwa - nowotarski, nowosądecki, tatrzański i limanowski. Są to obszary o wybitnych walorach przyrodniczo-krajobrazowych, niezniszczonych w wyniku industrializacji oraz o zachowanej autentycznej kulturze wiejskiej, co czyni je niezwykle atrakcyjnymi dla turystów. Również tradycja obsługi ruchu turystycznego jest na tych terenach dość długa, sięgająca XIX w. Istotnym czynnikiem rozwoju agroturystyki w tym rejonie są niekorzystne dla produkcji rolniczej warunki przyrodnicze oraz duże rozdrobnienie gospodarstw rolnych.

Tab. 2. Gminy o największej liczbie gospodarstw agroturystycznych w 2007 i 2014 r.

\begin{tabular}{|l|r|l|r|}
\hline \multicolumn{1}{|c|}{ Wyszczególnienie } & $\mathbf{2 0 0 7}$ & \multicolumn{1}{c|}{ Wyszczególnienie } & $\mathbf{2 0 1 4}$ \\
\hline Powiat tatrzański: & & Powiat tatrzański: & \\
Bukowina Tatrzańska & 160 & Zakopane & 47 \\
Biały Dunajec & 88 & Biały Dunajec & 37 \\
Kościelisko & 57 & Bukowina Tatrzańska & 31 \\
Poronin & 60 & Poronin & 25 \\
& & Kościelisko & 20 \\
\hline Powiat nowotarski: & 165 & Powiat nowotarski: & \\
Czorsztyn & 54 & Czarny Dunajec & 66 \\
Krościenko nad Dunajcem & 49 & Ochotnica Dolna & 28 \\
Raba Wyżna & 27 & Raba Wyżna & 24 \\
Czarny Dunajec & & Powiat nowosądecki: & \\
\hline Powiat nowosądecki: & 32 & Piwniczna-Zdrój & 37 \\
Muszyna & 27 & Krynica-Zdrój & 36 \\
Grodek nad Dunajcem & 11 & Gródek nad Dunajcem & 35 \\
Łososina & 10 & Muszyna & 23 \\
Rytro & & Powiat limanowski: & \\
\hline Powiat limanowski: & 24 & Dobra & 18 \\
Niedźwiedź & 18 & Niedźwiedź & 15 \\
Dobra & 16 & Laskowa & 11 \\
Laskowa & & Mszana Dolna & \\
\end{tabular}




\begin{tabular}{|l|r|l|r|}
\hline Powiat krakowski & & Powiat krakowski: & \\
Jerzmanowice-Przeginia & 23 & Sułoszowa & 11 \\
Sułoszowa & 18 & Wielka Wieś & 11 \\
Wielka Wieś & 12 & Jerzmanowice-Przeginia & 9 \\
\hline Powiat gorlicki & & Powiat gorlicki: & \\
Uście Gorlickie & 47 & Uście Gorlickie & 27 \\
Ropa & 15 & Sękowa & 19 \\
\hline
\end{tabular}

Źródło: opracowanie na podstawie: Turystyka polska w 2008 roku, układ regionalny (2009) oraz danych z portali internetowych gmin i powiatów województwa małopolskiego

Zaś powiaty: olkuski, chrzanowski, oświęcimski, o atrakcyjnych walorach środowiskowych, cechuje nieproporcjonalnie mniejsza liczba gospodarstw agroturystycznych. Jest to wynik uprzemysłowienia i wysokiego poziomu zurbanizowania tych obszarów. Odnotowano natomiast wzrost zainteresowania tą działalnością w jednej z gmin tego regionu - Zatorze (powiat oświęcimski). Jest to efekt konsekwentnej promocji tradycji hodowli karpia na tym terenie (tzw. Dolina Karpia). Równie nieliczne gospodarstwa agroturystyczne znajdują się w typowo rolniczych powiatach - miechowskim i proszowickim, w których nie ma tradycji turystycznych. Mają one również bardzo niskie wskaźniki udziału osób lepiej wykształconych, co wpływa m.in. na niewielką liczbę pozarolniczych podmiotów gospodarczych (Tracz, 2013; Uliszak, 2013).

Ryc. 1. Rozmieszczenie gospodarstw agroturystycznych w województwie małopolskim według gmin w $2014 \mathrm{r}$.

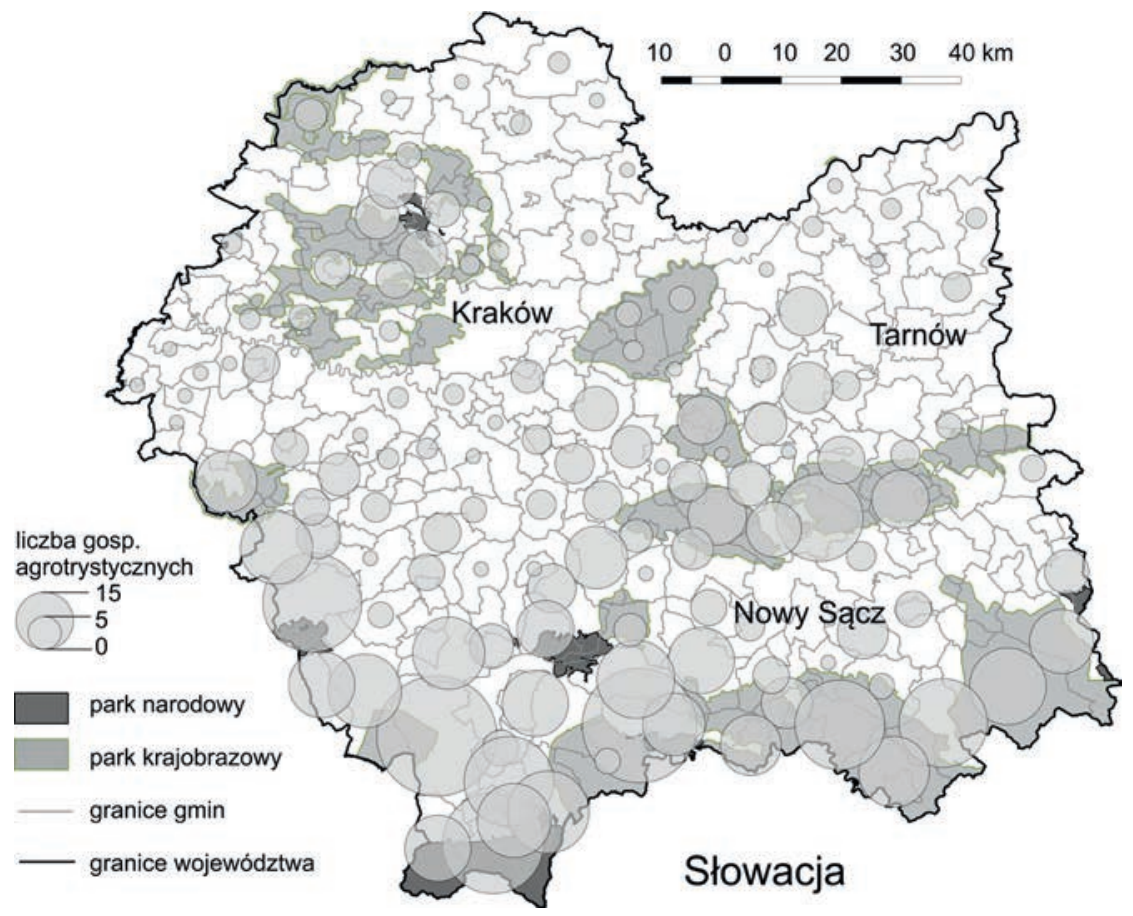

Źródło: opracowanie własne na podstawie danych z portali turystycznych gmin i powiatów 
Największa liczba gospodarstw zlokalizowana jest na atrakcyjnych pod względem turystycznym obszarach górskich i pogórskich: na Podhalu (w gminach Czarny Dunajec, Zakopane, Biały Dunajec), w Pieninach (w gminach Czorsztyn, Szczawnica i Krościenko nad Dunajcem), Beskidzie Sądeckim (w gminach Piwniczna-Zdrój, Krynica-Zdrój, Gródek nad Dunajcem), Gorcach i Beskidzie Wyspowym (w gminach Niedźwiedź, Laskowa i Dobra), Beskidzie Makowskim (w gminach Wiśniowa, Tokarnia, Raciechowice) oraz na Wyżynie Krakowsko-Częstochowskiej (w gminie Wielka Wieś, Sułoszowa, Skała, Klucze).

Generalnie należy stwierdzić, że w czterech powiatach położonych w południowej części województwa małopolskiego znajduje się aż 60,3\% wszystkich gospodarstw agroturystycznych działających w regionie (ryc. 1, tab. 2). W porównaniu z 2007 r. w 2014 r. odnotowano spadek liczby gospodarstw agroturystycznych na Podhalu - w powiecie tatrzańskim (tab. 2). Intensywny rozwój pensjonatów i małych hoteli spowodował, że agroturystyka stała się mało konkurencyjna dla coraz bardziej wymagającego turysty. Dlatego część osób zdecydowała się przejść na działalność związaną z turystyką wiejską (np. wynajem kwater). Wiele gospodarstw rolnych świadczących usługi agroturystyczne zaprzestało ostatecznie typowej działalności rolniczej. Nie mogą zatem one oferować zainteresowanym produktów z gospodarstwa, takich jak np. produkty żywnościowe, udział w pracach gospodarskich. Wiele z tych ofert jest więc tylko z nazwy gospodarstwami agroturystycznymi. Dodatkowo rozwój infrastruktury masowej turystyki na Podhalu (np. Bukowina Tatrzańska, Kościelisko) spowodował spadek zainteresowania kwaterami agroturystycznymi osób poszukujących „ciszy i spokoju”.

Odnotowano także znaczną liczbę gospodarstw agroturystycznych w bliskim sąsiedztwie Krakowa (powiat krakowski i wielicki). Są to gospodarstwa nastawione na turystykę weekendową, a ponadto wykorzystując bliskość Krakowa, oferują stosunkowo tanie noclegi dla zainteresowanych miastem turystów.

Odnosząc te wyniki do zdiagnozowanych i potwierdzonych w literaturze czynników lokalizacji gospodarstw agroturystycznych w Polsce (Drzewiecki, 2009; Sikora, 2012), stwierdzono, że w województwie małopolskim zostały one potwierdzone co do atrakcyjności przyrodniczo-krajobrazowej i kulturowej, tradycji obsługi ruchu turystycznego, niskiego zurbanizowania. Małe zurbanizowanie i uprzemysłowienie oraz rolnictwo tradycyjne nie są wystarczającymi atutami dla rozwoju agroturystyki w północnej części województwa małopolskiego. Wyraźnie dostrzega się zależność regionalną między popytem a podażą usług agroturystycznych. Turyści, mając do wyboru bardzo zróżnicowaną ofertę usług agroturystycznych w południowej części województwa, znacznie częściej będą ją wybierać niż oferty w innych powiatach.

Niewątpliwie w ostatnich latach czynnikami wpływającymi na rozwój agroturystyki są coraz częściej uwarunkowania społeczno-gospodarcze. Perspektywa zmniejszającej się dochodowości z produkcji rolnej i wysoki poziom bezrobocia na obszarach wiejskich wymusza na ludności działania przedsiębiorcze i poszukiwanie źródeł zarobkowania. Istnieje pozytywna korelacja między poziomem zarejestrowanego bezrobocia a liczbą funkcjonujących gospodarstw agroturystycznych. Przykładowo, w powiecie limanowskim poziom bezrobocia jest jednym z najwyższych w regionie (18,6\% w 2013 r.), a równocześnie powiat ten zajmuje on czwartą pozycję w województwie pod względem liczby funkcjonujących gospodarstw agroturystycznych (Bajgier-Kowalska, 2014). Również poziom wykształcenia ludności wiejskiej wpływa na podejmowanie działań przedsiębiorczych i samozatrudnienia. Stwierdzono, że w północno-wschodniej części województwa, gdzie jest stosunkowo niższy poziom wykształcenia ludności, występuje także najmniej gospodarstw agroturystycznych (ryc. 1). 
Na obszarach o dużym nasyceniu ofert agroturystycznych coraz bardziej uwidacznia się zjawisko konkurencyjności. Podmioty zabiegają nie tylko o liczbę turystów, co przekłada się bezpośrednio na dochodowość przedsięwzięcia, a także na zindywidualizowane wymagania klientów. Obserwowane zjawisko potwierdziły przeprowadzone przez autorów badania pilotażowe. $\mathrm{Z}$ analiz ofert zamieszczonych na stronach internetowych gospodarstw agroturystycznych oraz badań kwestionariuszowych wynika, że 98,5\% gospodarstw w regionie przyjmuje gości przez cały rok. Oferta turystyczna kierowana jest do szerokiej grupy turystów. Gospodarstwa te przygotowane są na przyjmowanie rodzin z dziećmi (100\%), osób starszych (15\%), osób niepełnosprawnych (2\%) i grup zorganizowanych (60\%). Część gospodarstw specjalizuje się w ofertach tematycznych (45\%). Większość badanych gospodarstw agroturystycznych w stałym programie oferuje możliwość uprawiania różnych form rekreacji i turystyki kwalifikowanej (turystyka piesza, rowerowa, konna, narciarska, wędkarstwo, kajakarstwo i inne). W badanych gospodarstwach standard usług jest wysoki. Turyści mają do dyspozycji pokoje gościnne z łazienką (91\%), możliwość korzystania z aneksu kuchennego (100\%) lub możliwość całodziennego wyżywienia (43\%), a 51\% gospodarstw oferuje zakup produktów pochodzących z własnego gospodarstwa. Coraz więcej gospodarstw inwestuje w rozwój nowych technologii. Wyposażenie pokoi w TV jest już standardem, a dostępność do Internetu stale się zwiększa. W badanej grupie gospodarstw wynosiła ona 90\%. Dodatkowe udogodnienia dla wypoczywających stanowią: place zabaw dla dzieci (52\%), zajęcia edukacyjne dla dzieci (6\%), miejsca do gier i zabaw ruchowych (57\%), udział w pracach gospodarskich (3\%), pokaz i nauka wypieku chleba, przygotowywanie przetworów owocowych, warzywnych i serowarskich $(6 \%)$ oraz uczestnictwo w pokazach i warsztatach rękodzielnictwa (garncarstwo, kowalstwo, koronkarstwo, strzyżenie owiec) - 12,5\%. Ponadto większość gospodarstw oferuje grzybobranie, połów ryb, zwiedzanie okolicy z przewodnikiem, możliwość wypożyczenia sprzętu sportowego i rekreacyjnego oraz uczestnictwo w sezonowych imprezach kulturalno-sportowych (kuligi, zawody narciarskie, festyny folklorystyczne, festiwale tematyczne).

W odpowiedzi na panującą modę spędzania wolnego czasu w kontakcie z naturą i spożywania produktów ekologicznych część gospodarstw agroturystycznych przekształca się w gospodarstwa ekoagroturystyczne. Gospodarstwa te w 2014 r. stanowiły 1,6\% ogółu gospodarstw agroturystycznych w województwie. W 2007 r. było zarejestrowanych 29 takich podmiotów, a w 2014 r. już tylko 20, najwięcej w powiecie limanowskim (http://www.eko.radom.com.pl/ bga/index.php).

\section{Innowacyjne produkty usług agroturystycznych województwa małopolskiego}

Województwo małopolskie, jako pierwszy region w Polsce, posiada aż trzy certyfikowane produkty turystyki wiejskiej. Każdy z nich oferuje atrakcyjne formy pobytu, dostosowane do określonych grup odbiorców i ich oczekiwań. Są to tzw. innowacje popytowe, czyli odpowiadające na potrzeby otoczenia, ale też produktowe, ponieważ oferują nowe rodzaje usług. Należą do nich: „Małopolska Wieś Pachnąca Ziołami”, „Małopolska Wieś dla Dzieci” oraz „Małopolska Wieś dla Seniorów”. Wszystkie te produkty są przejawem aktywności i działań przedsiębiorczych Sądeckiej Organizacji Turystycznej przy wsparciu samorządu województwa małopolskiego. Oferowane są także inne produkty z profilowaną ofertą usług turystycznych (tab. 3). 
Tab. 3. Wybrane oferty agroturystyki w województwie małopolskim

\begin{tabular}{|c|c|c|}
\hline Nazwa oferty & Cechy oferty & Miejsce występowania \\
\hline \multicolumn{3}{|l|}{$\begin{array}{l}\text { I. Certyfikowane } \\
\text { produkty turystyki } \\
\text { wiejskiej }\end{array}$} \\
\hline $\begin{array}{l}\text { 1. „Małopolska Wieś } \\
\text { Pachnąca Ziołami” }\end{array}$ & $\begin{array}{l}\text { specjalizacja w zakresie uprawy } \\
\text { i szerokiego wykorzystania ziół } \\
\text { w kuchni regionalnej i medycynie } \\
\text { niekonwencjonalnej } \\
\end{array}$ & $\begin{array}{l}22 \text { gospodarstwa w południowej } \\
\text { i wschodniej części województwa }\end{array}$ \\
\hline $\begin{array}{l}\text { 2. „Małopolska Wieś dla } \\
\text { Dzieci” }\end{array}$ & $\begin{array}{l}\text { specjalizacja w zakresie aktywnego, } \\
\text { urozmaiconego i bezpiecznego } \\
\text { spędzania czasu wolnego dzieci } \\
\text { i rodziców połączona z edukacją } \\
\text { przez zabawę }\end{array}$ & $\begin{array}{l}16 \text { gospodarstw w różnych } \\
\text { częściach regionu }\end{array}$ \\
\hline $\begin{array}{l}\text { 3. „Małopolska Wieś dla } \\
\text { Seniorów” }\end{array}$ & $\begin{array}{l}\text { specjalizacja w zakresie aktywnej } \\
\text { rekreacji, kierowana do seniorów } \\
\text { (np. jazda konna, narty, piesze } \\
\text { wędrówki, rowery), połączona } \\
\text { z kuchnią regionalną }\end{array}$ & $\begin{array}{l}15 \text { gospodarstw w południowej } \\
\text { części województwa }\end{array}$ \\
\hline \multicolumn{3}{|l|}{$\begin{array}{l}\text { II. Tematyczne produkty } \\
\text { turystyki wiejskiej }\end{array}$} \\
\hline $\begin{array}{l}\text { 1. „Małopolska Wieś } \\
\text { w Siodle” }\end{array}$ & $\begin{array}{l}\text { specjalizacja w rekreacji konnej } \\
\text { oraz lokalnej tradycji i produktach } \\
\text { regionalnych }\end{array}$ & $\begin{array}{l}15 \text { gospodarstw w różnych } \\
\text { częściach województwa }\end{array}$ \\
\hline 2. „Zagrody Edukacyjne” & $\begin{array}{l}\text { specjalizacja w tematycznych } \\
\text { zajęciach związanych z hodowlą } \\
\text { zwierząt, uprawą roślin oraz } \\
\text { poznaniem dawnych zawodów (np. } \\
\text { rolnik, młynarz, kowal, garncarz) }\end{array}$ & $\begin{array}{l}19 \text { gospodarstw w różnej części } \\
\text { województwa }\end{array}$ \\
\hline $\begin{array}{l}\text { 3. „Małopolska Miodowa } \\
\text { Kraina” }\end{array}$ & $\begin{array}{l}\text { specjalizacja w zakresie pasiek } \\
\text { ekologicznych i rozwoju tradycji } \\
\text { pszczelarskich oraz wykorzystania } \\
\text { miodu w kuchni i medycynie } \\
\text { ludowej }\end{array}$ & $\begin{array}{l}20 \text { gospodarstw w południowej } \\
\text { części województwa }\end{array}$ \\
\hline $\begin{array}{l}\text { 4. „Małopolski Szlak } \\
\text { Winny” }\end{array}$ & $\begin{array}{l}\text { specjalizacja w uprawie winnej } \\
\text { latorośli i tradycyjnej produkcji wina }\end{array}$ & $\begin{array}{l}20 \text { gospodarstw w różnych } \\
\text { częściach województwa }\end{array}$ \\
\hline $\begin{array}{l}\text { III. Tradycyjna } \\
\text { agroturystyka }\end{array}$ & $\begin{array}{l}\text { pobyt w gospodarstwie } \mathrm{z} \text { udziałem } \\
\text { w pracach gospodarskich lub } \\
\text { polowych }\end{array}$ & $\begin{array}{l}\text { niewielka liczba gospodarstw } \\
\text { rozproszonych po całym } \\
\text { województwie }\end{array}$ \\
\hline
\end{tabular}

Źródło: opracowanie własne na podstawie: http://malopolskie.pl/Turystyka/

Województwo to zajmuje również pierwsze miejsce w Polsce pod względem liczby skategoryzowanych gospodarstw agroturystycznych. Aktualnie 277 gospodarstw, tj. 22\% ogółu gospodarstw w regionie, jest rekomendowanych przez Polską Federację Turystyki Wiejskiej „GG”. Kategoryzacja obejmuje dwie grupy: „Wypoczynek u rolnika” i „Wypoczynek na wsi”. Należy nadmienić, że proces kategoryzacji gospodarstw agroturystycznych jest dobrowolny. 
W wyniku planowanych działań podejmowanych przez samorząd województwa liczba skategoryzowanych obiektów agroturystycznych stale wzrasta.

\section{Zakończenie}

Województwo małopolskie należy do tych regionów, które dzięki posiadanym walorom środowiska naturalnego i dziedzictwa kulturowego są najbardziej predysponowane do rozwoju specjalistycznej oferty agroturystycznej, odwołującej się do autentycznej kultury wiejskiej i „powrotu do natury”. Odpowiada to aktualnym trendom w turystyce międzynarodowej. Aby proces ten mógł przebiegać właściwie, należy dążyć nie tylko do podnoszenia jakości oferowanych usług i udoskonalania produktu turystycznego, lecz także do zachowania jakości środowiska przyrodniczego, będącego głównym atutem regionu. Problem ten poruszany jest również przez turystów, co wykazały badania ankietowe prowadzone m.in. przez K. Krauze (2011) i A. Niedziółkę (2010a, 2010b).

W wielu gminach południowej części województwa obserwuje się proces przechodzenia z agroturystyki na działalność gospodarczą związaną z usługami turystycznymi. Potwierdzeniem tego jest zauważalny spadek liczby gospodarstw agroturystycznych, przy równoległym zwiększeniu liczby innych ofert turystycznych (pensjonaty, hotele, kwatery prywatne, ośrodki wypoczynkowe). Na tych terenach turystyka staje się dominującym źródłem utrzymania dużej grupy ludności wiejskiej. Gospodarstwa agroturystyczne przez ostatnie lata coraz częściej były takimi tylko z nazwy. Coraz mniejszy udział produkcji rolnej, a co za tym idzie zmniejszająca się oferta produktów spożywczych wytwarzanych w gospodarstwie, powoduje spadek zainteresowania tą ofertą potencjalnych turystów. Gospodarstwa agroturystyczne, oferując produkty pochodzące $z$ zewnątrz, tracą swój główny atut, a jakością bazy noclegowej nie mogą dorównać pensjonatom i hotelom.

Równolegle intensywny rozwój turystyki, o wybitnych cechach komercyjnych, jak ma to miejsce w części gmin powiatu tatrzańskiego, powoduje, że zmniejsza się zainteresowanie turystów nastawionych na "ciszę i spokój” ofertą gospodarstw agroturystycznych położonych w tym obszarze. Większym zainteresowaniem potencjalnych turystów cieszą się oferty agroturystyczne z sąsiednich powiatów - nowotarskiego, sądeckiego i limanowskiego, co przekłada się na liczbę funkcjonujących tam gospodarstw agroturystycznych (ryc. 1, tab. 2).

Województwo małopolskie jest przykładem, gdzie wspólne działania przedsiębiorcze samorządów lokalnych, urzędu marszałkowskiego, przedsiębiorców i lokalnych organizacji pozarządowych (stowarzyszeń, kół gospodyń wiejskich) umożliwiają kreowanie innowacyjnej, atrakcyjnej oferty agroturystycznej. Jednym z przykładów wsparcia jest realizacja programu „Małopolska Agroturystyka - rozwój i promocja oferty turystyki wiejskiej”. Dotychczasowe działania skupiają się na szkoleniach adresowanych do osób zainteresowanych prowadzeniem gospodarstwa agroturystycznego, wsparciu finansowym przeznaczonym na modernizacje bazy lokalowej, wzbogacaniu oferty oraz akcjach promocyjnych. Aktualnie istnieje potrzeba, aby działania gmin oraz stowarzyszeń agroturystycznych w większym stopniu zmierzały $\mathrm{w}$ stronę promowania zachowania rolniczego charakteru wsi, z którym związana jest agroturystyka i ekoturystyka. Postępujący zanik działalności rolniczej może spowodować osłabienie autentycznej kultury ludowej, ograniczenie produkcji „zdrowej” żywności oraz zmiany w krajobrazie rolniczym. 
Istniejące w województwie małopolskim uwarunkowania demograficzne, przyrodnicze i historyczne powodują, że w strukturze agrarnej rolnictwa przeważają i przeważać będą drobnotowarowe gospodarstwa. W tych warunkach istotnym wyzwaniem dla działań przedsiębiorczych wśród rolników prowadzących agroturystykę jest przezwyciężenie niechęci do wszelkich form zrzeszania się i wspólnych inicjatyw, wynikających z przeszłości historycznej. Wspólne inicjatywy w zakresie kreowania nowych ofert turystycznych, powiązanych $\mathrm{z}$ istniejącymi zasobami i ich promocja mogą stanowić kluczową kwestię w zakresie przetrwania i rozwoju małych gospodarstw rolnych i powiązanych z nimi usług turystycznych.

\section{Literatura}

References

Bajgier-Kowalska, M. (2014). Agroturystyka jako czynnik rozwoju gospodarczego obszarów wiejskich powiatu limanowskiego. W: Z. Zioło, T. Rachwał (red.), Problematyka 30. Jubileuszowej Międzynarodowej Konferencji Naukowej nt. „Problematyka badawcza przemian strukturalnych przemysłu $i$ ustug $w$ układach przestrzennych". Kraków-Warszawa: ZPiGP UW, Uniwersytet Pedagogiczny im. Komisji Edukacji Narodowej, 12-13.

Bański, J. (red.). (2010). Atlas rolnictwa Polski. Warszawa: IGiPZ PAN.

Bański, J., Stola, W. (2002). Przemiany struktury przestrzennej i funkcjonalnej obszarów wiejskich w Polsce. Studia Obszarów Wiejskich, 3, 1-121.

Bednarczyk, M. (red.). (2010). Przedsiębiorczość w turystyce. Zasady i praktyka. Warszawa: CeDeWu.

Bednarek-Szczepańska, M., Bański, J. (2014). Lokalizacyjne uwarunkowania rozwoju gospodarstw agroturystycznych w Polsce. Przegląd Geograficzny, 96(2), 243-260.

Bieńkowski, A. (2001). Turystyka jako forma wielofunkcyjnego rozwoju obszarów wiejskich. Gospodarka w Praktyce i Teorii, 1(8), 106-116.

Busby, G., Rendle, S. (2000). The transition from tourism on farms to farm tourism. Tourism Management, 21(6), 635-642.

Butler, R.W. (1998). Rural recreation and tourism. W: B. Ilbery (ed.), The geography of rural change. Harlow: Addison Wesley Longman, 211-232.

Charakterystyka gospodarstw rolnych w województwie małopolskim (2010). Kraków: GUS.

Colton, J.W., Bissix, G. (2005). Developing agritourism in Nova Scotia: issues and challenges. Journal of Sustainable Agriculture, 27(1), 91-112.

Dorocki, S., Szymańska, A.I., Zdon-Korzeniowska, M. (2012). Polskie gospodarstwa agroturystyczne jako przedsiębiorstwa rodzinne. Przedsiębiorczość i Zarzadzanie, 13(8), 45-60.

Dorocki, S., Szymańska, A.I., Zdon-Korzeniowska, M. (2013). Przedsiębiorstwa agroturystyczne w gospodarce opartej na wiedzy. Prace Komisji Geografii Przemystu Polskiego Towarzystwa Geograficznego, 24, 38-58.

Drucker, P.F. (1992). Innowacje i przedsiębiorczość. Praktyka i zasady. Warszawa: PWE.

Drzewiecki, M. (2001). Podstawy agroturystyki. Bydgoszcz: Oficyna Wydawnicza Ośrodka Postępu Organizacyjnego.

Drzewiecki, M. (2009). Agroturystyka wspótczesna w Polsce. Gdańsk: WSTiH.

Durydiwka, M. (2003). Tourism as a factor of the activation the rural areas in Poland. Acta Universitatis Caroline. Geographica, 1, 53-58.

Durydiwka, M. (2012). Czynniki rozwoju i zróżnicowanie funkcji turystycznej na obszarach wiejskich w Polsce. Warszawa: WGiSR UW.

Durydiwka, M. (2013). Tourism function in rural area in Poland. Special diversity and changing trends. Miscellanea Geographia, 17(3), 5-11.

Eurostat (2014, 11 listopada). Pozyskano z: http://epp.eurostat.ec.europa.eu/portal/page/portal/eurostat/home. 
Fabiańska, K. (1986). Planowanie rozwoju przedsiębiorstwa. Warszawa: PWE.

Fleischer, A., Tchetchik, A. (2005). Does rural tourism benefit from agriculture? Tourism Management, 26, 493-501.

Gannon, A. (1994). Rural tourism as a factor in rural community economic development for economies in transition. Journal of Sustainable Tourism, 2(1/2), 51-60.

Gospodarka rolna w województwie małopolskim. Raport. (2012). Kraków: Urząd Marszałkowski.

Jagusiewicz, A., Łopaciński, K. (2010). Ocena stanu turystyki wiejskiej i agroturystyki w Polsce w latach 2005-2009. Pozyskano z: http://bip.minrol.gov.pl /FileRepozy-tory/FileRepozytoryShowImage. aspx?item_id $=37813$

Jędrysiak, T. (2010). Wiejska turystyka kulturowa. Warszawa: PWE. Kierunki rozwoju turystyki dla województwa małopolskiego na lata 2008-2013. (2008). Kraków: Urząd Marszałkowski Województwa Małopolskiego.

Kortan, J. (red.). (1997). Podstawy ekonomiki i zarządzania przedsiębiorstwem. Warszawa: C.H. Beck.

Krajewski, K., Śliwa, J. (2004). Lokalna przedsiębiorczość w Polsce. Uwarunkowania rozwoju. Warszawa: Wydawnictwo Naukowe WZ UW.

Krauze, K. (2011) Agroturystyka w gminie Czorsztyn. Państwo i Społeczeństwo, 1, 133-148.

Krzyżanowska, K. (red.). (2010). Przedsiębiorczość na obszarach wiejskich. Stan i perspektywy rozwoju. Warszawa: SGGW.

Kuciński, K. (red.). (2010). Przedsiębiorczość a rozwój regionalny w Polsce. Warszawa: Difin.

Kurdyś-Kujawska, A. (2010). Turystyka wiejska jako szansa rozwoju gmin i powiatów na przykładzie powiatu gryfickiego. Folia Pomeranae Universitatis Technologiae Stietinensis. Oeconomica, 284(61), $53-60$.

Majewska, J. (2006). Wyzwalanie ducha przedsiębiorczości w środowisku społecznym gminy dla rozwoju lokalnego. Przedsiębiorczość - Edukacja, 2, 91-100.

Małopolska agroturystyka. Atlas gospodarstw agroturystycznych (2013, 16 sierpnia). Pozyskano z: http:// www.malopolskie.pl/Pliki/2012/agroturystyka.indd.pdf

McGehee, N., Kim, K. (2004). Motivation for agri-tourism entrepreneurship. Journal of Travel Research, $43,161-170$.

Niedziółka, A. (2010a). Rola otoczenia instytucjonalnego w rozwoju usług agroturystycznych w gminach podhalańskich. Studia i Materiały „Miscellanea Oeconomicae”, 14(1), 111-119.

Niedziółka, A. (2010b). Uwarunkowania rozwoju infrastruktury agroturystycznej na przykładzie powiatu nowosądeckiego. Infrastruktura i Ekologia Terenów Wiejskich, 1, 219-230.

Phillip, S., Hunter, C., Blackstock, K. (2010). A typology for defining agritourism. Tourism Management, $31,754-758$.

Powszechny Spis Rolny. Raport z wyników województwa małopolskiego. (2011). Kraków: GUS.

Przygodzka, R. (1999). Zróżnicowanie funkcjonalne obszarów wiejskich województwa białostockiego. Roczniki Naukowe SERIA, t. 1, z. 1, 317-322.

Roberts, L., Hall, D. (2001). Rural tourism and recreation principles to practice. Oxon-New York: CABI, 231.

Rocznik Statystyczny Województwa Małopolskiego (2014). Warszawa: GUS.

Semczuk, M., Uliszak, R., Wiedermann, K. (2013). Uwarunkowania rozwoju pozarolniczej działalności gospodarczej obszarów wiejskich województwa małopolskiego. Prace Komisji Geografii Przemysłu Polskiego Towarzystwa Geograficznego, 23, 43-56.

Sikora, J. (2008). Gospodarstwa agroturystyczne w świetle sytuacji społeczno-ekonomicznej polskiej wsi. W: S. Bosiacki (red.), Gospodarka turystyczna w XXI wieku, Poznań: AWF, 25.

Sikora, J. (2012). Agroturystyka. Przedsiębiorczość na obszarach wiejskich. Warszawa: C.H. Beck.

Sikora, J., Jęczmyk, A. (2006). Agroturystyka przykładem przedsiębiorczości w wielofunkcyjnym rozwoju terenów wiejskich. W: Rola turystyki w strategii i polityce rozwoju gospodarki regionalnej: zbiór materiałów pokonferencyjnych. Gdańsk: WSTiH, Fundacja Rozwoju Uniwersytetu Gdańskiego.

Sznajder, M., Przezbórska, L. (2006). Agroturystyka. Warszawa: PWE. 
Strategia rozwoju województwa małopolskiego na lata 2011-2020. Małopolska 2020. (2011). Kraków: Urząd Marszałkowski Województwa Małopolskiego.

Systematyka i charakterystyka gospodarstw rolnych w województwie małopolskim. (2011). Kraków: GUS.

Tracz, M. (2013). Rola edukacji w budowaniu kapitału społecznego w Polsce. Prace Komisji Geografii Przemystu, 23, 134-145.

Turystyka polska w 2008 roku, układ regionalny (2009). Warszawa: Instytut Turystyki.

Turystyka wiejska, w tym agroturystyka, jako element zrównoważonego i wielofunkcyjnego rozwoju obszarów wiejskich. Raport końcowy. (2012). Warszawa: IGiPZ PAN.

Uliszak, R. (2013). Wizja wsi małopolskiej - rok 2050 - spodziewane scenariusze zmian. Studia Obszarów Wiejskich, 31, 67-83.

Wojciechowska, J. (2009). Procesy i uwarunkowania rozwoju agroturystyki w Polsce. Łódź: Wydawnictwo Naukowe UŁ.

Zdon-Korzeniowska, M. (2009). Jak ksztaltować regionalne produkty turystyczne? Teoria i praktyka. Kraków: Wydawnictwo Naukowe UJ.

Zdon-Korzeniowska, M. (2011). Marketing terytorialny jako forma działań przedsiębiorczych samorządów terytorialnych w Polsce. Przedsiębiorczość - Edukacja, 7, 188-196.

Zioło, Z. (2006). Rola przedsiębiorczości w podnoszeniu konkurencyjności społeczeństwa i gospodarki. Przedsiębiorczość - Edukacja, 2, 10-17.

Zioło, Z. (2007). Rola przedsiębiorczości w aktywizacji gospodarczej - zarys modelu. Przedsiębiorczość Edukacja, 3, 10-17.

Zioło, Z. (2011). Rola przedsiębiorczości w warunkach nasilających się procesów globalizacji. Przedsiębiorczość - Edukacja, 7, 10-23.

Małgorzata Bajgier-Kowalska, dr, Krakowska Akademia im. Andrzeja Frycza Modrzewskiego. Zainteresowania naukowo-badawcze autorki koncentrują się wokół problemów geomorfologicznych oraz zagadnień z zakresu geografii regionalnej. Prowadzone badania dotyczą również problematyki rozwoju turystyki i rekreacji, a głównie zagadnień uwarunkowania rozwoju i funkcjonowania regionów turystycznych na świecie, analizy przestrzennego zróżnicowania zagospodarowania turystycznego oraz wielkości ruchu turystycznego.

Małgorzata Bajgier-Kowalska, $\mathrm{PhD}$, the scientific and research issues as well as the publication themes are concentrated on the geomorphology problems and the issues concerning regional geography. Author's research concentrate also on the problem of tourism and recreation growth, especially on the question of development conditions and functioning of tourist regions in the world including the analyses of spatial differentiation of tourist infrastructure and size of tourism itself.

\section{Adres/Address:}

Krakowska Akademia im. Andrzeja Frycza Modrzewskiego

ul. Gustawa Herlinga-Grudzińskiego 1

30-705 Kraków, Polska

e-mail:malbajkow@interia.pl

Mariola Tracz, dr, Szkoła Wyższa im. Bogdana Jańskiego w Krakowie, geograf, dydaktyk geografii, członkini Polskiego Towarzystwa Geograficznego. Zainteresowania naukowe autorki skupiają się wokół dydaktyki geografii (programy nauczania, edukacja geograficzna a rozwój kompetencji, kształcenie nauczycieli geografii i podstaw przedsiębiorczości, historia geografii i jej dydaktyki), geografii społecznogospodarczej (polityka edukacyjna państwa, edukacja a rozwój gospodarczy).

Mariola Tracz, PhD, geographer, geography educator, member of the Polish Geographical Society, interested in: geography education (curriculum development, geography education and competency development, geography and entrepreneurship teacher training, history of geography and their didactics) socio-economic geography (educational policy, education and economic development). 


\section{Adres/Address:}

Szkoła Wyższa im. Bogdana Jańskiego

Wydział Zamiejscowy w Krakowie

os. Niepodległości 19

31-862 Kraków, Polska

e-mail: mtracz-62@o2.pl

Radosław Uliszak, dr, Krakowska Akademia im. Andrzeja Frycza Modrzewskiego, geograf, zainteresowania naukowe autora obejmują geografię społeczno-gospodarczą, w szczególności geografię rolnictwa i terenów wiejskich, a także wykorzystanie nowoczesnych technologii (GIS) w pracy geografa i nauczyciela.

Radosław Uliszak, $\mathrm{PhD}$, geographer, interested in human geography, geography of agriculture and rural areas and use of modern technology (GIS) at geographers' and teachers' work.

\section{Adres/Address:}

Krakowska Akademia im. Andrzeja Frycza Modrzewskiego

ul. Gustawa Herlinga-Grudzińskiego 1

30-705 Kraków, Polska

e-mail: krecony@yahoo.com 